\title{
Studi Pelaksanaan Program Praktek Kerja Industri Kompetensi Keahlian Teknik Kendaraan Ringan di SMK Negeri 1 Lembah Melintang
}

\author{
Ahmad Rifaldi ${ }^{{ }^{*}}$, Toto Sugiarto ${ }^{1}$ \\ ${ }^{1}$ Jursan Teknik Otomotif FT UNP, Fakultas Teknik, Universitas Negeri Padang \\ "e-mail: ahmadrifaldi941@gmail.com
}

(Diterima: 19 April 2020, direvisi: 16 Mei 2020, disetujui: 30 Mei 2020)

\begin{abstract}
Abstrak
Penelitian ini bertujuan untuk mengetahui sejauh mana pelaksanaan Program Praktik Kerja Industri pada Kompetensi Keahlian Teknik Kendaraan Ringan di SMKN 1 Lembah Melintang. Penelitian ini merupakan penelitian kuantitatif dengan metode pendekatan deskriptif. Teknik pengambilan sampel pada penelitian ini adalah dengan metode Taro Yamane. Kesiapan pelaksanaan administrasi dan organisasi tinggi yaitu $86,9 \%$. Kesiapan biaya yaitu 88,3\%. Kesiapan pengelolaan program yaitu $85,3 \%$. Kesiapan guru pembimbing yaitu $72,9 \%$. Kesiapan fasilitas sarana dan prasarana di industri yaitu 76,4\%. Pelaksanaan kegiatan Praktek Kerja Industri di industri yaitu $79,1 \%$. Pelaksanaan monitoring yaitu $88 \%$. Pelaksanaan uji kompetensi dan sertifikasi yaitu 49,9\%. Pelaksanaan evaluasi yaitu $66,3 \%$
\end{abstract}

Kata Kunci: Pelaksanaan, Praktek Kerja Industri, Teknik Kendaraan Ringan

\begin{abstract}
This study aims to determine the extent of the implementation of the Industrial Work Practices Program in Light Vehicle Engineering Skills Competency at SMKN 1 Melintang. This is a quantitative study research. The sampling technique in this study is to use the Taro Yamane formula. The high administration and organizational readiness is $86.9 \%$. Cost readiness is $88.3 \%$. Program management readiness is $85.3 \%$. Teacher counselor readiness is $72.9 \%$. Readiness of facilities and infrastructure in the industry is $76.4 \%$. The implementation of industrial work practices in the industry is $79.1 \%$. Implementation of monitoring is $88 \%$. The implementation of competency test and certification is $49.9 \%$. The evaluation was $66.3 \%$.
\end{abstract}

Keywords: Implementation, Industrial Work Practices, Light Vehicle Engineering 


\section{PENDAHULUAN}

Pendidikan menengah kejuruan adalah pendidikan pada jenjang pendidikan menengah yang mengutamakan pengembangan kemampuan siswa untuk melaksanakan jenis pekerjaan tertentu seperti yang tertuang dalam (PP No. 29 tahun 1990 Bab 1 ayat 3) Sekolah Menengah Kejuruan adalah bentuk satuan pendidikan di jalur pendidikan menengah kejuruan. Salah satu kebijakan baru dalam pembangunan pendidikan yang di perkenalkan pada saat Kabinet Pembangunan VI di tahun 1994 adalah link and match. Secara harfiah, "link" berarti terkait, menyangkut proses yang harus interaktif, dan " match" berarti cocok, menyangkut hasil yang harus sesuai atau sepadan.

Pendidikan Sistem Ganda adalah suatu bentuk penyelenggaraan pendidikan keahlian kejuruan, yang memadukan secara sistematik dan sinkron program pendidikan di sekolah dan program belajar melalui kegiatan bekerja langsung pada bidang yang relevan, terarah untuk mencapai penguasaan keahlian tertentu[4]. Menurut Andrey Rahman (2018) Praktek Kerja Industri merupakan suatu tahap persiapan profesional dimana seorang siswa (peserta) yang hampir menyelesaikan studi (pelatihan) secara formal bekerja di lapangan dengan survrise oleh seorang administrator yang kompeten dalam jangka waktu tertentu yang bertujuan mengembangkan kemampuan untuk melaksanakan tanggung jawab. Praktek Kerja Industri juga merupakan bagian dari kebutuhan proses pendidikan yang tidak terpisahkan dari kurikulum pendidikan. Tujuan Praktek Kerja Industri seperti yang terdapat dalam sistem Pendidikan Sistem Ganda, yaitu : (a) Menghasilkan tenaga kerja yang memiliki keahlian profesional yaitu tenaga kerja yang memiliki tingkat pengetahuan, keterampian, dan etos kerja yang sesuai dengan tuntutan lapangan kerja (b) Meningkatkan dan memperkokoh keterkaitan dan kesepadanan (link and match) antara lembaga pendidikan-pelatihan kejuruan dan dunia kerja (c) Meningkatkan efisiensi proses pendidikan dan pelatihan tenaga kerja yang berkualitas professional (d) Memberi pengakuan dan penghargaan terhadap pengalama kerja sebagai bagain dari proses pendidikan [1].

Kesiapan adalah merupakan suatu keadaan yang mendorong seorang secara keseluruhan untuk melakukan reaksi atau melakukan pekerjaan secara fisik, mental, pengetahuan mapun keterampilan. Kesiapan pelaksanaan Praktek Kerja Industri oleh sekolah adalah ketersediaan sekolah dalam melaksanakan dan mempraktekkan Praktek Kerja Industri. Secara garis besar kesiapan sekolah dalam menghadapi Praktek Kerja Industri, peneliti membagi menjadi empat yaitu kesiapan administrasi dan organisasi, kesiapan biaya, kesiapan pengelolaan program, dan kesiapan guru pembimbing.

Kesiapan administrasi sekolah yang dimaksut dalam penelitian ini di artikan sebagai ketersediaan usaha dan kegiatan yang meliputi pengelolaan dan pengaturan yang di tandai dengan : (1) kesiapan perencanaan prosedur pelaksanaan Praktek Kerja Industri, (2) Pembentukan organisasi dan penunjukan personil pengelola Praktik Kerja Industri, (3) Proses surat menyurat. Biaya adalah pengorbanan sumber ekonomi, yang diukur dalam satuan uang, yang telah terjadi atau yang kemungkinan akan terjadi untuk tujuan tertentu. Biaya tersebut diantaranya untuk pembekalan siswa, monitoring, administrasi, dan segala keperluan lainnya. Pengelolaan biaya juga harus transparan dan dilakukan pelaporan di akhir pelaksanaan Praktik Kerja Industri. 
Secara umum kata pengelolaan dapat didefinisikan sebagai suatu rangkaian pekerjaan atau usaha yang dilakukan oleh sekolompok orang untuk melakukan serangkaian kerja dalam mencapai tujuan tertentu. pengelolaan adalah suatu rangkaian kegiatan yang berintikan perencanaan, pengorganisasian, penggrerakan dan pengawasan yang bertujuan menggali dan memanfaatkan sumber daya alam yang dimiliki secara efektif untuk mencapai tujuan organisasi yang telah di tentukan.

Kesiapan guru pembimbing yang di maksut dalam penelitian ini adalah ketersediaan guru yang memenuhi syarat-syarat yang telah ditetapkan yang di tunjukkan dengan ciri-ciri : (1) mendapatkan informasi tentang Praktek Kerja Industri, (2) Memahami masalah Praktek Kerja Industri, (3) Mampu memberikan pengarahan kepada siswa, (4) Menyiapkan sarana prosedur belajar mengajar dalam Praktek Kerja Industri, (5) Keterlibatan dalam organisasi pengelola Praktek Kerja Industri, dan (6) Memiliki pengalam industri.

Pengertian kelengkapan fasilitas praktek kerja industri yang dimaksut dalam penelitian ini adalah ketersediaan kelengkapan sarana dan prasarana yang memudahkan praktek di industri yang meliputi : tersedianya ruang praktek, ruangan khusus untuk ganti pakaian kerja dan menaruh barang pribadi, dan kelengkapan sarana alat keselamatan kerja.

Kegiatan siswa peserta Praktek Kerja Industri yang dimaksut dalam penelitian ini adalah aktivitas atau pekerjaan siswa di industri yang dikelompokkan berdasarkan jenis komponen yang mencerminkan isi program dan pelatihan dalam Praktek Kerja Industri, ysng terdiri dari lima komponen di atas dan juga sikap dan perilaku siswa selama melaksanakan pekerjaan.

Monitoring yaitu kegiatan yang dilakukan untuk menegecek penampilan dari aktivitas yang sedang dikerjakan. Secara terperinci kegiatan monitoring dimaksutkan untuk : (1) Mengetahui keterlaksanaaan program siswa di dunia usaha/dunia industri yang telah direncanakan, (2) Mengetahui sikap dan perilaku siswa selama melaksankan Praktek Kerja Industri, (3) Menegtahui hambatan-hambatan yang dialami siswa selama melaksanakan Praktek Kerja Industri beserta pemecahan masalahnya.

Uji kompetensi menurut Depdikbud adalah bentuk evaluasi hasil belajar yang dilakukan oleh pemakai tamatan dan lembaga profesi sebagai strategi memperoleh tamatan yang memiliki produktif standar yang di persyaratkan pemakai, sedangkan yang di maksut sertifikasi adalah pemberian sertifikat kepada tamatan atau siswa yang telah dapat mengusai kemampuan standar atau keahlian kejuruan yang di peroleh melalui ujian kompetensi (Depdikbud).

Evaluasi Praktek Kerja Industri adalah proses pengumpulan data dan menganalisisnya untuk meilai program Praktek Kerja Industri yang bertujuan untuk mendapatkan umpan balik dan sebagai pertanggungjawaban atas tugas yang telah di emban oleh suatu lembaga atau organisasi tertentu. fungsi evaluasi adalah menyiapkan informasi untuk keperluan pengambilan kebijakan tentang suatu program. Prosedur dalam mengadakan evaluasi terdiri atas beberapa tahapan. Langkah-langkah evaluasi itu terdiri atas : menetapkan tujuan program, memilih alat yang layak, pelaksanaan pengukuran, memberikan skor, menganalisa dan menginterpresentasikan skor, membuat catatan yang baik, dan menggunakan hasil-hasil pengukuran.. 


\section{METODA}

Penelitian ini merupakan penelitian kuantitatif dengan metode pendekatan deskriptif, data yang diperoleh dari subyek penelitian dianalisis sesuai dengan metode statistik kuantitatif yang digunakan kemudian diinterpretasikan. Teknik pengambilan sampel pada penelitian ini adalah dengan menggunakan rumus Taro Yamane. Subjek yang akan digunakan dalam penelitian ini adalah kelompok kerja pendidikan sistem ganda, guru pembimbing dan siswa kelas XII TKR SMK N 1 Lembah Melintang pada semester ganjil tahun ajaran 2019-2020. Jumlah kelompok kerja pendidikan sistem ganda sebanyak 5 orang, guru pembimbing sebanyak 5 orang dan siswa kelas XII TKR di SMK N 1 Lembah Melintang pada tahun ajaran 2019/2020 adalah 20 orang siswa. Penelitian ini dilakukan di SMKN 1 Lembah Melintang. Secara umum, prosedur penelitian dapat di bagi menjadi tiga tahap yaitu : tahap persiapan, tahap pelaksanaan, dan tahap penyelesaian. Teknik pengumpulan data dilakukan dengan cara memberikan pernyataan/pertanyaan dalam bentuk instrumen (angket) tertutup, kepada seluruh subyek penelitian untuk kemudian dijawabnya.

Instrumen adalah alat ukur yang digunakan dalam mengumpulkan data. Jenis instrumen yang digunakan dalam penelitian ini adalah berupa pernyataan/pertanyaan dalam bentuk instrumen tertutup. instrumen disusun berdasarkan indikator-indikator yang terkandung dalam definisi operasional masing-masing variabel. Angket (kuesioner) yang digunakan didesain berdasarkan Skala Likert yang berisi sejumlah pernyataan/pertanyaan yang menyatakan objek yang hendak diungkap.

\section{HASIL DAN PEMBAHASAN}

Penelitian ini merupakan penelitian kuantitatif dengan metode pendekatan deskriftif, data yang di peroleh dari subyek penelitian dianalisis sesuai dengan metode statistik yang digunakan kemudian di interpretasikan. Subyek penelitian ini meliputi kelompok kerja Pendidikan Sistem Ganda, guru pembimbing, dan siswa yang semuanya berjumlah 30 orang.

Variabel yang diteliti dalam penelitian ini adalah kesiapan administrasi dan organisasi, kesiapan biaya, kesiapan pengelolaan program, kesiapan guru pembimbing, kesiapan fasilitas praktek di industri, pelaksanaan praktek di dunia industri, pelaksanaan monitoring, pelaksanaan uji kompetensi dan sertifikasi, dan pelaksanaan evaluasi. Telah disusun beberapa angket yang kemudian ditanyakan kepada subyek penelitian sesuai dengan angket masing-masing. Hasil dari angket kemudian direkapitulasi dan dideskrepsikan Dan kesemua Sembilan variabel tersebut dapat dilihat rangkumannya pada tabel 1 hingga tabel 9.

Tabel 1. Kesiapan Administrasi dan Organisasi

\begin{tabular}{cllcc}
\hline Variabel & \multicolumn{1}{c}{ Aspek Kesiapan } & $\begin{array}{c}\text { No. Butir Pada } \\
\text { Instrumen }\end{array}$ & Prosentase (\%) \\
\hline $\begin{array}{c}\text { Kesiapan } \\
\text { Administrasi } \\
\text { dan }\end{array}$ & 1. & $\begin{array}{l}\text { Pembentukan Organisasi dan } \\
\text { Penunjukan Personil Pengelola }\end{array}$ & $1-6$ & $86,7 \%$ \\
Organisasi & 2. & $\begin{array}{l}\text { Pelaksanaan surat menyurat/ } \\
\text { kesekretariatan }\end{array}$ & $11-18$ & $85 \%$ \\
& 3. & Pemetaan DU/DI & $7-10$ & $89 \%$ \\
\hline \multicolumn{2}{c}{ Rata-rata } & $86,9 \%$ \\
\hline
\end{tabular}


Tabel 2. Kesiapan Biaya

\begin{tabular}{cclcc}
\hline Variabel & \multicolumn{1}{c}{ Aspek Kesiapan } & $\begin{array}{c}\text { No. Butir Pada } \\
\text { Instrumen }\end{array}$ & Prosentase (\%) \\
\hline \multirow{3}{*}{ Kesiapan Biaya } & 1. & Sumber biaya pelaksanaan & $1-2$ & $70 \%$ \\
& & PRAKERIN & $3--4$ & $94 \%$ \\
& 2. & Pengelolaan biaya PRAKERIN & 5 & $96 \%$ \\
\hline & 3. & Pelaporan & & $88,3 \%$ \\
\hline
\end{tabular}

Tabel 3. Kesiapan Pengelolaan Program

\begin{tabular}{lccc}
\hline Variabel & Aspek Kesiapan & $\begin{array}{c}\text { No. Butir Pada } \\
\text { Instrumen }\end{array}$ & Prosentase (\%) \\
\hline Kesiapan & 1. Pembekalan siswa & $1-2$ & $86 \%$ \\
Pengelolaan & 2. Koordinasi pelaksanaan PRAKERIN & $3-4$ & $78 \%$ \\
Program & 3. $\quad$ Sosialisai kepada siswa peserta PRAKERIN & $5-8$ & $92 \%$ \\
\hline Rata-rata & \multicolumn{2}{c}{$85,3 \%$} \\
\hline
\end{tabular}

Tabel 4. Guru Pembimbing

\begin{tabular}{|c|c|c|c|}
\hline Variabel & Aspek Kesiapan & $\begin{array}{l}\text { No. Butir Pada } \\
\text { Instrumen }\end{array}$ & $\begin{array}{c}\text { Prosentase } \\
(\%)\end{array}$ \\
\hline $\begin{array}{l}\text { Kesiapan Guru } \\
\text { Pembimbing }\end{array}$ & $\begin{array}{l}\text { 1. Mendapatkan informasi tentang } \\
\text { PRAKERIN } \\
\text { 2. Mengetahui konsep PRAKERIN } \\
\text { 3. Pengalam industry } \\
\text { 4. Keterlibatan dalam organisasi } \\
\text { PRAKERIN maupun kegiatan kesiswaan } \\
\text { 5. Prosedur belajar mengajar pada } \\
\text { PRAKERIN }\end{array}$ & $\begin{array}{c}1-2 \\
3-6 \\
7-9 \\
10-12\end{array}$ & $\begin{array}{c}78 \% \\
\\
95 \% \\
44,7 \%\end{array}$ \\
\hline Rata-rata & & & $72,9 \%$ \\
\hline
\end{tabular}

Tabel 5. Kesiapan fasilitas Praktik di Dunia Usaha/Dunia Industri

\begin{tabular}{lclcc}
\hline \multicolumn{1}{c}{ Variabel } & \multicolumn{1}{c}{ Aspek Kesiapan } & $\begin{array}{c}\text { No. Butir Pada } \\
\text { Instrumen }\end{array}$ & Prosentase (\%) \\
\hline & 1. & Keadaan ruang praktek & $1-2$ & $86,5 \%$ \\
& 2. & Ketersediaan alat praktek & 3 & $84 \%$ \\
Kesiapan fasilitas & 3. & $\begin{array}{l}\text { Ketersediaan ruang praktek dan ruang } \\
\text { pendukung lainnya }\end{array}$ & $4-5$ & $62 \%$ \\
& 4. & $\begin{array}{l}\text { Ketersediaan sarana keselamatan } \\
\text { kerja }\end{array}$ & $6-9$ & $61,7 \%$ \\
& 5. & Ketersediaan bahan praktek & 10 & $88 \%$ \\
\hline Rata-rata & & & $76.4 \%$ \\
\hline
\end{tabular}

Tabel 6. Pelaksanaan Praktek Kerja Industri di dunia usaha/dunia industri

\begin{tabular}{lllcc}
\multicolumn{1}{c}{ Variabel } & & \multicolumn{1}{c}{ Aspek Kesiapan } & \multicolumn{1}{c}{$\begin{array}{c}\text { No. Butir Pada } \\
\text { Instrumen }\end{array}$} & Prosentase (\%) \\
\hline $\begin{array}{l}\text { Pelaksanaan PSG } \\
\text { di Dunia }\end{array}$ & 1. & $\begin{array}{l}\text { Komponen } \\
\text { Kejuruan/praktek industri }\end{array}$ & Peahlian \\
$\begin{array}{l}\text { Usaha/Dunia } \\
\text { Industri }\end{array}$ & 2. & Sikap dan perilaku kerja & $1-6$ & $78,3 \%$ \\
Rata-rata & & & $7-21$ & $79,9 \%$ \\
\hline
\end{tabular}

Tabel 7. Pelaksanaan Monitoring

\begin{tabular}{lcrc}
\hline Variabel & Aspek Kesiapan & $\begin{array}{l}\text { No. Butir } \\
\text { Instrumen }\end{array}$ & Pada \\
\hline Monitoring & $1 . \quad$ Keterlaksanaan program & $1-2$ & $90 \%$ \\
\hline
\end{tabular}




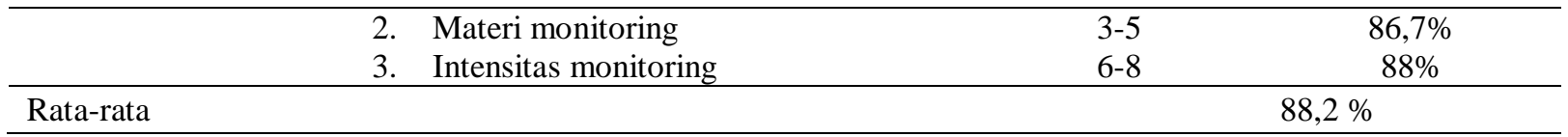

Tabel 8. Pelaksanaan Uji Kompetensi dan Sertifikasi

\begin{tabular}{lllcc}
\hline \multicolumn{1}{c}{ Variabel } & \multicolumn{1}{c}{ Aspek Kesiapan } & $\begin{array}{c}\text { No. Butir Pada } \\
\text { Instrumen }\end{array}$ & Prosentase (\%) \\
\hline \multirow{3}{*}{ Uji Kompetensi } & 1. & Keterlaksanaan & $1-3$ & $70,7 \%$ \\
dan Sertifikasi & 2. & Materi uji kompetensi & $4-5$ & $48 \%$ \\
& 3. & Sertifikasi & $8-10$ & $54,7 \%$ \\
& 4. & Sarana dan prasarana & 6 & $40 \%$ \\
Rata-rata & 5. & Biaya & 7 & $36 \%$ \\
\hline
\end{tabular}

Tabel 9. Pelaksanaan Evaluasi

\begin{tabular}{lllcc}
\hline Variabel & & \multicolumn{1}{c}{ Aspek Kesiapan } & $\begin{array}{c}\text { No. Butir Pada } \\
\text { Instrumen }\end{array}$ & Prosentase (\%) \\
\hline \multirow{4}{*}{ Evaluasi } & 1. & pelaksanaan evaluasi & 1 & $76 \%$ \\
& 2. & Tim evaluasi & $2-3$ & $70 \%$ \\
& 3. & Komponen yang di evaluasi & 4 & $64 \%$ \\
& 4. & Pengolahan evaluasi & 5 & $64 \%$ \\
Rata-rata & 5. & Pelaporan hasil evaluasi & 6 & $64 \%$ \\
\hline
\end{tabular}

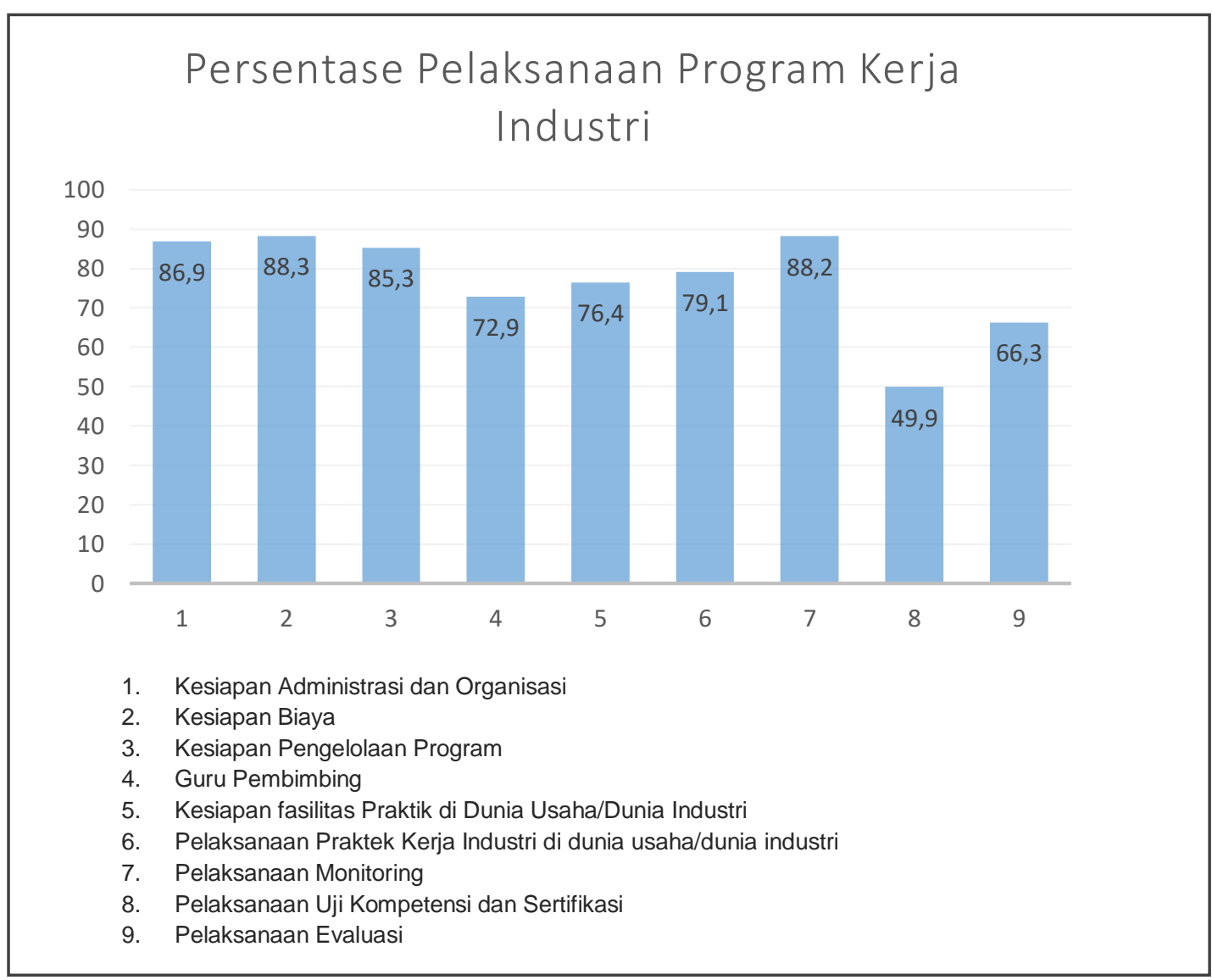

Gambar 1. Deskripsi grafis pelaksanaan Program Kerja Industri

Kesiapan pelaksanaan administrasi dan organisasi mencapai tingkat kesiapan sangat tinggi yaitu 86,9\%. Kesiapan biaya mencapai tingkat kesiapan sangat tinggi yaitu 88,3\%. 
Kesiapan pengelolaan program mencapai tingkat kesiapan sedang sangat tinggi 85,3\%. Kesiapan guru pembimbing mencapai tingkat kesiapan tinggi yaitu 72,9\%. Fasilitas sarana dan prasarana di industri mencapai tingkat kesiapan tinggi yaitu $76,4 \%$. Pelaksanaan kegiatan Praktek Kerja Industri di industri mencapai tingkat kesiapan tinggi yaitu $79,1 \%$. Pelaksanaan monitoring mencapai tingkat kesiapan sangat tinggi yaitu $88 \%$. Pelaksanaan uji kompetensi dan sertifikasi mencapai tingkat kesiapan sangat sedang yaitu 49,9\%. Pelaksanaan evaluasi mencapai tingkat kesiapan tinggi yaitu 66,3\%.

\section{SIMPULAN DAN SARAN}

Berdasarkan data yang terkumpul dan pembahasan hasil penelitian, maka dapat ditarik simpulan sebagai berikut : Kesiapan pelaksanaan administrasi dan organisasi mencapai tingkat kesiapan sangat tinggi yaitu 86,9\%. Kesiapan biaya mencapai tingkat kesiapan sangat tinggi yaitu $88,3 \%$. Kesiapan pengelolaan program mencapai tingkat kesiapan sedang sangat tinggi $85,3 \%$. Kesiapan guru pembimbing mencapai tingkat kesiapan tinggi yaitu 72,9\%. Fasilitas sarana dan prasarana di industri mencapai tingkat kesiapan tinggi yaitu 76,4\%. Pelaksanaan kegiatan Praktek Kerja Industri di industri mencapai tingkat kesiapan tinggi yaitu 79,1\%. Pelaksanaan monitoring mencapai tingkat kesiapan sangat tinggi yaitu $88 \%$. Pelaksanaan uji kompetensi dan sertifikasi mencapai tingkat kesiapan sangat sedang yaitu 49,9\%. Pelaksanaan evaluasi mencapai tingkat kesiapan tinggi yaitu 66,3\%.

Saran kepada pihak terkait yaitu Dirjendikmen, Dinas Pendidikan, Kadin, dan instansi terkait supaya menambah lagi perangkat pendukung Praktek Kerja Industri baik berupa buku pedoman, peraturan-peraturan, surat keputusan maupun perangkat yang lain sehingga semua pihak dapat mengetahui dan menggunakan sebagai pedoman dalam pelaksanaan Praktek Kerja Industri. Kelompok kerja agar dapat mencarikan lokasi dunia usaha/dunia industri yang akan digunakan Praktek Kerja Industri yang memiliki skala menengah ke atas yang memiliki manajemen yang bagus dan sarana memadai sehingga dapat menunjang pembelajaran siswa. Pihak sekolah hendaknya dapat memberi kesempatan pada guru produktif untuk dapat mengikuti pelatihan-pelatihan di industri, magang, atau diklat yang berhubungan dengan perindustrian sehingga kemampuan dan kualitas guru dapat meningkat. Pihak pokja hendaknya berkoordinasi dengan dunia usaha/dunia industri terkait pelaksanaan uji kompetensi dan sertifikasi sehingga siswa benar-benar ada pengakuan secara tertulis di kompetensi tertentu.

\section{REFERENSI}

[1] Andrey Rahman, Hasan Maksum. (2018). Kontribusi Pengalaman Afektif Praktik Kerja Industri Terhadap Kesiapan Siswa Memasuki Dunia Kerja Kelas XII Jurusan Teknik Kendaraan Ringan Di SMK N 1 Tilatang Kamang. Jurnal Penelitian Universitas Negeri Padang.

[2] Arikunto, Suharsimi. (2006). Organisasi dan Administrasi Pendidikan Teknologi dan Kejuruan. Jakarta : Direktorat Jenderal Pendidikan

[3] Atmojo. (2006). Pelaksanaan Pendidikan Sistem Ganda di Industri di Daerah Istimewa Yogyakarta. Skripsi. IKIP Yogyakarta.

[4] Pramana, Herdi B.P.P. (2015). Pelaksanaan Praktek Kerja Industri (Prakerin) Kompetensi Keahlian Teknologi Kendaraan Ringan SMK Negeri 3 Pacitan

Tahun 2013/2014. Skripsi. Universitas Negeri Yogyakarta 
[5] Siska, Riza. (2014). Persepsi Siswa Terhadap Pelaksanaan Praktek Kerja Industri Siswa SMKN 1 Batu Sangkar dan SMK Progresif di Kabupaten Tanah Datar. Skripsi. Universitas Negeri Padang

[6] Sugiyono. (2012). Metode Penelitian Kuantitatif Kualitatif dan R\&D. Bandung: Alfabeta

[7] Syahputra, Yudi. (2011). Hambatan-Hambatan Yang di Hadapi Siswa Dalam Pelaksanaan Praktek Kerja Industri di SMK Negeri 1 Sutera Pesisir Selatan. Skripsi. Universitas Negeri Padang 